Open Access

\title{
Competition for attention in the Chinese bureaucracy
}

Hong Lian

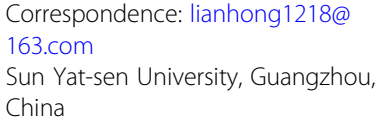

Correspondence: lianhong1218@ 163.com

Sun Yat-sen University, Guangzhou, China

\begin{abstract}
Researchers of the Chinese bureaucracy generally believe that policy promotion depends on the power of the party committees because they have absolute authority in China. This intuitive argument, however, lacks support from rigorous empirical research and theoretical analyses. Through close observation of the Bureau of Justice, this paper analyzes how differentiated authority affects organizational interaction and triggers the corresponding government behavior. The paper finds that while the functional bureaus could use professional authority to carry out policies, they nevertheless choose to rely on the administrative authority of the government and the political authority of the party committee. We illustrate the process, mechanism, and consequences of attention competition. The process reflects that the party committee has real authority, while the government has formal authority and the functional bureaus have only symbolic authority. This differentiated authority has three consequences: (1) the "Matthew effect" of the authority structure, (2) functional bureaus competing fiercely for the party committees' attention at the expense of accomplishing routine work, and (3) rule of the leader's personal preference instead of the rule of law in governance.
\end{abstract}

Keywords: Attention competition, Multi-task principal-agent theory, Differentiated authority, Government behavior

\section{Research question}

From 2013 to 2015, the author closely observed two institutional innovations in a provincial justice bureau. The first occurred in legal services. The justice bureau provided public legal services at the grassroots level, such as legal notarization, counseling, and assistance. The second was an allocation of legal advisers. The justice bureau allocated contracted lawyers to villages (communities). The institutional innovation was mainly implemented by justice bureaus at each local administrative level, with the coordination of the corresponding local governments and related bureaus. In theory, only by using professional guidance could the justice bureaus push the implementation of the work within the justice system, government systems, and other bureaus. One the one hand, the justice bureau could use their assessment/evaluation system to push local justice bureaus to implement the policy; on the other hand, the provincial, municipal, and county justice offices could send letters requesting cooperation from relevant government offices. In this paper, this top-down professional guidance is called linear competition for attention.

(c) The Author(s). 2018 Open Access This article is distributed under the terms of the Creative Commons Attribution 4.0 International License (http://creativecommons.org/licenses/by/4.0/), which permits unrestricted use, distribution, and reproduction in any medium, provided you give appropriate credit to the original author(s) and the source, provide a link to the Creative Commons license, and indicate if changes were made. 
However, one of the characteristics of the Chinese government behavior is curvilinear competition for attention rather than linear competition. The functional bureaus could use the right of professional authority to carry out the work or policy, but instead appealed to use the authority of the party committee. Specifically, the provincial Bureau of Justice does not choose to use professional authority but bypasses it to compete for the provincial government's attention and put pressure on local subordinate governments and bureaus by means of the authority status of the provincial party committee and the provincial government. Compared to the linear competition, curvilinear competition intentionally makes a detour. It illustrates the following four strategies.

The first is significance. In order to attract the attention of the provincial government, the primary strategy of the provincial Justice Bureau is to emphasize the importance of institutional innovation to the provincial government. Emphasizing innovation helps promote economic development and maintain social stability. The provincial government is very concerned, and to which it attaches great importance. This importance reflects the significance mechanism. Akerlof (1991) points out that significance is one of the mechanisms involved when organizations handle affairs, namely, giving high weight to significant or vivid events and placing a lower degree of attention on less-significant events.

The importance of this can be described as the economy and society developed till today must have judicial legal services. Then we talk about serious contradictions and determine some importance. However, the importance cannot look too empty; it should be appropriate and proper. (20130718, Deputy Director of the Bureau of Justice)

Public security is like Western medicine, such as antibiotics, which rigidly maintains stability, while the judiciary is like traditional Chinese medicine, such as cordyceps sinensis, which is a flexible prevention method. The institutional innovation of the Bureau of Justice can be transformed from a passive, static, rigid stability maintenance to an initiative, dynamic, flexible stability maintenance. (20130507, Director of the Bureau of Justice)

The second strategy is time pressure, that is, the emphasis on urgency. The importance is a construct of static meaning, while the urgency emphasizes dynamic meaning. It indicates that there is no time for waiting but an urgent need to start, since waiting could lead to a crisis such as hurting economic development and social stability. Urgency reflects the time pressure mechanism. Game theory believes that time pressure is an important factor in the negotiation process; both sides of the game use time pressure to influence the negotiation process, negotiation capability, and negotiation result (Rubinstein 1982; Gibbons 1992).

The provincial Bureau of Justice tried to use the time pressure mechanism to enhance their bargaining ability with the provincial government.

Urgency means urgent! If you don't start, there will be a serious crisis! When something happens, do not let the common people go upstairs or on a bridge; they will jump off the building or bridge! But let them go to court. Let the provincial government leadership feel that going to court is really important and really necessary, they have no other choice. If such a feeling was conveyed to them then the urgency is well advocated! (20130806, Deputy Director of the Bureau of Justice) 
The third strategy is data reliability. Importance and urgency cannot be groundless, and they need to be proved by first-hand data. In order to demonstrate importance and urgency, the provincial Bureau of Justice spent much time on investigation and survey in the province and other provinces. They specifically invited third-party experts and scholars to participate in the research process to indicate the relative objectivity and neutrality of the research in order to signal the reliability of the data to the provincial party committee and provincial government:

These things are not made up by our Bureau of Justice by racking our brains. We have spent a long time on it and conducted a lot of research. When it is reported to the leadership of the provincial party committee and provincial government, there must be a research report. You see, we cooperate with an institution of higher education such as Sun Yat-sen University; we fill this report with the research and arguments of experts. (20130718, Deputy Director of the Bureau of Justice)

The fourth strategy is the comparison mechanism. Much of the report that the provincial Bureau of Justice presented to the provincial party committee and government emphasized that when other countries developed to China's current stage, there was a relevant system to promote legal services or legal advisers. It is necessary for China to implement such a system. This uses a comparison mechanism to demonstrate the necessity for China to adopt a similar system. This international comparison aims to establish approximate causal relations (Weick 1979) and contributes to transmitting legitimate signals to the provincial party committee and government, indicating that institutional innovation aims to meet the needs of a widely accepted institutional environment (Meyer and Rowan 1977).

The expert of the Bureau of Justice sent a signal by including the opinion of a Nobel Prize winner: "When discussing poverty in the past, Nobel Prize in Economics [laureate] Amartya Sen believes that it is due to the fact that the poor lack the ability to work or lack education. But in fact poverty occurs because rights are not well protected; there is no right to express your opinions, or a lack of equal legal opportunities and care. Therefore poverty is the result of poor legal protection. We will send such a message to the leadership of the provincial party committee and government. Since the international communities are paying attention to this, it is also necessary for our Office of Justice to do so." (20130105, Head of the Expert Group of the Bureau of Justice)

The above paragraphs show four strategies of curvilinear competition, of which "importance" is the prerequisite of "urgency." If system innovation is not important to the provincial party committee and government, even though time is pressing, it remains an unattractive option. In addition, first-hand data (data reliability) and international comparison (comparison mechanism) are the specific demonstrations of "importance" and "urgency" that strengthen the effects of competition for attention.

This paper focuses on the question of why the functional bureau relies on leadership authority of the party committee without using their professional authority to carry out policies. How authority structure affects organizational interaction and triggers the corresponding government behavior. Organizational theory points out that compared with business, governments often face multiple principals and multiple tasks (Wilson 1989; Dixit 1996). Can the traditional multi-task principal-agent theory explain the attention competition phenomenon? We next employ multi-task principal-agent theory to answer the above questions. 


\section{The traditional multi-principal and multi-task structure}

In the field of organizational economics, there is a series of research on the multiple principals, multiple agents, and multiple tasks (Yu and Guan 2005). This paper focuses on multiple principals, multiple tasks, and single agent, that is, a local government faces multiple superiors and multiple tasks. I next address how traditional organizational economic theory analyzes multi-task principal-agent structure and then assess its explanatory power regarding the government behavior.

\section{Multi-principal structure}

A government bureau is not an agent that represents a single organization and only assumes limited tasks; instead, it faces multiple principals and multiple tasks. Wilson's analysis of US government agencies points out that government has to face more complex multi-principal and multi-task environments than business does. The term "multiple principals" refers to each agent having to deal with several principals, with all principals trying to influence the agent's decision. "Multiple tasks" indicates that the government generally has multi-dimensional efforts (inputs) and outcomes (output), many of which are difficult to effectively observe and confirm (Wilson 1989). Based on Wilson's theory, Dixit (1996) further developed a multi-principal and multi-task model from the perspective of organizational economics. A basic conclusion of these studies is that multi-principal and multi-task structure presents a flat structure. The term "flat" usually refers to a nonhierarchical structure, for example, one that does not have many levels between the superior and subordinate. In this paper, the term "flat" refers to a number of superiors having equal status and influence, that is, a number of superiors are in a similar status and have the same weight in influencing subordinates.

First, there are multiple principals. Wilson et al. point out that US government agencies face multiple principals, such as legislative, judicial, executive, interest groups, society, and media (Wilson 1989; Dewatripont et al. 1999). Second, the status of the principals is flat; multiple principals have similar opportunities, weight, and ability to influence the decision of a sole agent. For example, the legislative, judicial, and executive branches of the separation of powers have the same authority status. In addition, the media and public opinion have the same opportunity to influence the decision of the sole agent (Wilson 1989). The above analysis can be summarized as follows:

Proposition 1.1 The traditional multi-principal structure presents a flat structure, i.e., the principals are multiple, and their statuses are relatively flat.

\section{Endogenous effects}

Organizational theory suggests that the organizational structure has an endogenous effect on members' behavior. For example, the bureaucratic structure shapes the regulatory compliance of officials. However, as time evolves, officials may end up with a goal substitution, that is, regulatory compliance is changed from a method into the ultimate goal, and instrument value is changed into the ultimate value (Merton 1940; Michels 1968). Some scholars also point out that when organizational structure is different (open structure, professional structure, or hierarchical structure), people's organizational interaction, reference comparison, and incentive intensity also differ (Cohen et al. 1972). Similarly, the flat structure also leads to some endogenous effects. 
The first is the competition between multiple principals. Principals with the same status may either cooperate or compete and are more likely to cooperate if they have the same interests and objectives. In this case of cooperation, multiple principals are equivalent to one principal and thus form a traditional single-principal agent problem. As Dixit (1996) puts it, if all principals can cooperate and provide a common incentive mechanism, then a suboptimal state can be achieved. However, in the real world, the interests and objectives of multiple principals are often different, and there are two mechanisms to weaken the mutual cooperation between the principals. The first mechanism is a split of authority. Each principal represents a kind of authority for subordinates. When the number of principals increases from one to several, the subordinate faces multiple authorities. Since the goals and interests of each principal are different, the principals may maximize their authority and expect subordinates to make great efforts on inputting and outputting their policy goals. Thus, the phenomenon of split authority occurs.

The second mechanism is a split of income. When multiple superiors cooperate, each superior can only share the total return of $1 / N$, with $N$ representing the number of superiors. This split of income easily motivates each superior to try to share the return with the peer authorities, leading to a decline of these peers' efforts and enthusiasm and thus affecting their cooperation (Aghion and Tirole 1997). Therefore, due to different interests and goals, the multi-principals who have the same status are more likely to compete with each other, and the degree of competition continues to increase along with the growing number of principals.

The second endogenous effect is the inter-group comparison between multiple principals. Reference group and relative comparison theories state that the comparative objects of individuals, groups, and organizations are more likely to be reference objects with more daily interactions, close status, or similar characteristics. Once a reference group is formed, these reference groups establish a competitive relationship, either explicitly or implicitly (Festinger 1954; Merton 1957; Akerlof 1982), such as comparing their history, prospects, positive or negative information, or improved conditions (Weick 1979). In the process of comparison, the groups may form a certain sense of relative deprivation or relative satisfaction. In the flat structure, because multiple principals have a similar status, they are more likely to form inter-group comparison and compete for the sole agent's attention.

The third endogenous effect is the quantification of task's reward and punishment. The term "multi-task" means that the principal has several tasks assigned to the agent, or the task assigned to the agent has multiple dimensions that may be conflicting, independent, or complementary (Holmstrom and Milgrom 1991). Studies have pointed out that the multiple tasks of government agencies are often immeasurable. From the perspective of input, many government tasks are often interdependent. The extent to which job performance or problems come from the individual or the team cannot be determined (Holmstrom and Milgrom 1991). From the perspective of output, the results and quality of government work are difficult to observe and confirm because they normally take effect after a long time (Tirole 1994). In this case, officials' performance is often difficult to measure, and thus their effort incentive may decrease or even disappear.

To achieve effective incentives, superiors often use the following two methods. The first is the quantified mechanism. The validity of multi-task output measurement differs. Usually, superiors quantify some important tasks with clear measurement, which 
will receive attention from the subordinates. The second method is the reward and punishment mechanism. Based on the quantification, the superiors reward or punish the quantified key tasks. If some tasks have greater pressure or consequences, such as the "one-veto rule," subordinates may pay more attention to them. The above conclusions can be summarized as follows:

Proposition 1.2 The flat structure results in competition between the multiple principals endogenously.

Proposition 1.3 The flat structure results in inter-group comparison between multiple principals endogenously.

Proposition 1.4 The multi-task incentive is mainly determined by the degree of quantification of reward and punishment.

\section{Organizational results}

The following organizational results can be formed under the above conditions. The first is the linear competition for attention. In the flat structure, superiors start the inter-group comparison, competing for the attention of the subordinate. Under the circumstances of limited subordinate resources and attention, whether several superiors can get the subordinate's attention in a timely manner will greatly affect the policy implementation. This inter-group competition for the subordinate's attention without appealing to highest leadership/political authority can be referred to as the linear competition for attention. The second result is the agent's low-powered incentive. Each superior has the motivation to impose strong incentives on the tasks with which they are concerned and want the subordinates to give priority to implementing their policies. When each superior selects an incentive mechanism, the subordinates face a series of different incentive schemes. Meanwhile, the incentive designs of the superiors often interact when the incentive intensity of some superior increases, resulting in the increased investment of the subordinate in this superior and a decreasing investment in other superiors. In other words, imposing a strong incentive on a subordinate who carries out the superior's policy intention is equivalent to penalizing the investment of other superiors in the subordinate's attention and implementation (Bernheim and Whinston 1986). In this case, the subordinate may be exhausted and put in a double squeeze, and will generally show low-powered incentive. As Dixit (1996) observes, compared to the private sector, the incentives in the public sector, especially in the government sector, are relatively weak. Figure 1 depicts the traditional multi-principal and multi-task structure.

The above discussion can be summarized as:

Proposition 1.5 In the flat structure, multiple principals directly compete for the agent's attention.

Proposition 1.6 In the flat structure, the agent generally shows low-powered incentives.

However, multi-task principal-agent theory in organizational economics can hardly explain the Chinese government behavior. First, it is difficult to explain the attention competition phenomenon. The above-mentioned theory points out that in traditional flat structure, the superior directly competes for the agent's attention. For example, the functional bureaus only need to use their professional authority to compete for the 


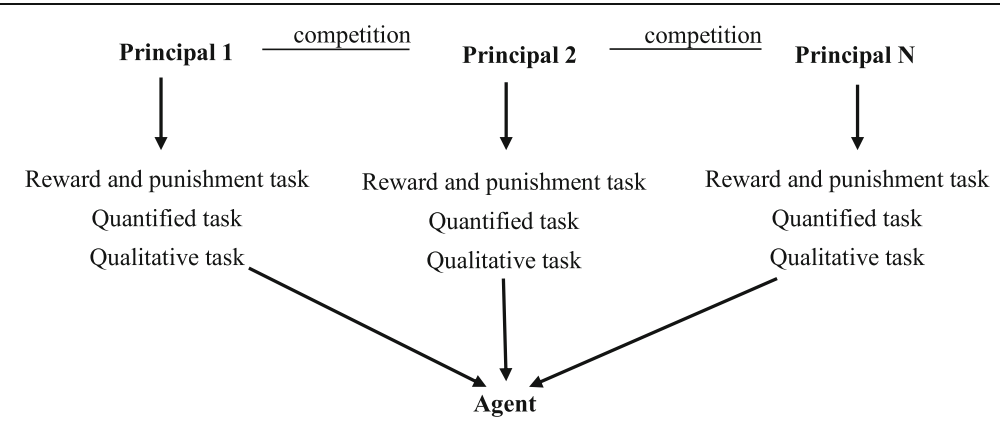

Organizational features:

(1) Multiple principals: Competition with each other; comparison between groups

(2) Multiple tasks: Quantification of reward and punishment incentives

(3) Agent: Low-powered incentives

(4) Multiple principals compete for agent's attention: Linear competition

Fig. 1 The traditional multi-principle and multi-task structure

subordinate's attention without resorting to other authorities. This is very different from functional bureaus' behavior in the real world, that is, in the actual operational process, the functional bureaus do not only rely on their professional authorities to work, but also choose to use the authority of the party committee to promote their work. From this perspective, the traditional framework may not be able to explain this phenomenon in China. Second, it is difficult to explain why high-powered incentive and low-powered incentive coexist. A subordinate can hardly be proactive and promising when facing multiple superiors and is subject to various constraints; this shows a low-powered incentive (Wilson 1989; Dixit 1996) and is not in line with China's reality. A series of studies have pointed out that the behaviors of Chinese officials have steadily demonstrated the coexistence of both high-powered incentive and low-powered incentive. For example, high-powered incentive exists in the field of economic development, aerospace technology, competitive sports, high-speed rail, disaster relief, and reconstruction, while in the areas of food safety, production safety, social security, and environmental governance, the incentives are relatively weak (Zhou 2007, 2014; Lian 2016).

\section{The Chinese multi-principal and multi-task structure}

Through close participant observation of the provincial justice bureau and the induction of other cases, this paper shows the inner structure of the Chinese government through the lens of the refined multi-task principal-agent theory based on China's context.

\section{Multi-principal structure}

The multi-principal characteristic of the Chinese government present is a ternary differentiated authority. Although local governments face a number of superiors, their priorities are mainly concentrated in three principals: the party committee, government, and functional bureaus. This judgment comes from the author's close participant observation and governmental documents from all levels in the country. A local government mainly receives three types of documents: party committee and government documents, government documents, and bureau normative documents. For example, the 
central-level government handles documents of the CPC Central Committee and the State Council, State Council documents, and normative documents of ministries and commissions. At the provincial level, there are documents of the provincial party committee and government, provincial government documents, and bureau normative documents. Documents of the city and county levels are similar. Existing studies have pointed out that government documents largely determine the attention distribution, daily schedules, and priorities of officials (Weber 1946; Lian 2015); to some extent, the three types of documents also represent three different principals.

Traditional theory holds that the statuses of multiple principals are similar, but the authority statuses of different Chinese state agencies vary greatly, which show a differentiated authority of the party committee $>$ government $>$ functional bureaus. Seeing from the perspective of authority, the local government and bureau consider the higher-level party committee to have real authority, the higher-level government has formal authority, and higher functional bureaus only have symbolic authority (Aghion and Tirole 1997; Zhou and Lian 2011). Seeing from the perspective of authority relations, the higher-level party committee has absolute leadership authority over the local government; accordingly, the other two major principals have administrative authority and professional authority over the local government, respectively. It is worth noting that the relationship between the party committee and the government has adjusted back and forth several times. At the beginning of the founding of new China, by emphasizing the separation of the party and the government, the party committee tended to avoid affecting government bureaus. However, in 1953, the Party Central Committee began to strengthen its leadership over government bureaus (He and Kong 2011). In 1958, Chairman Mao Zedong also stressed the party's leadership and principles and put forward the idea of "centralizing power on major issues and decentralizing power on minor issues; the party committee makes decisions, the government carries them out" (Party Literature Research Center of the CPC Central Committee 1993, 355). After 1987, with an emphasis on the separation of the party and the government, the power of the party committee significantly decreased, such as the revocation of party committees and the politics and law committee, and the revocation of party organizations in government bureaus (Zhao 2013). In recent years, the party committee has regained its power over the government. Accordingly, the business cards of government officials previously listed their government position first, but now list their party position first. In general, the party committee and the government are collectively referred to as government. However, from the above-mentioned historical evolution, they have strong heterogeneity and different authorities. Viewing the party committee and government as two independent variables is thus suitable and proper since they have different roles in China's state governance.

In summary, the Chinese government presents a ternary differentiated authority (Fig. 2). Fei Xiaotong (1998) uses the concept of "differentiated mode of association" (cha $x u$ ge ju) to describe the associational pattern in the traditional Chinese society in which people's social network is similar to a ripple in water-when one throws a stone into any part of a lake, the water ripples naturally push outward layer upon layer from the center stone. Utilizing this concept, this paper proposes a ternary differentiated authority, referring to the structure of Chinese state authority in which party leadership authority occupies the center, surrounded by 


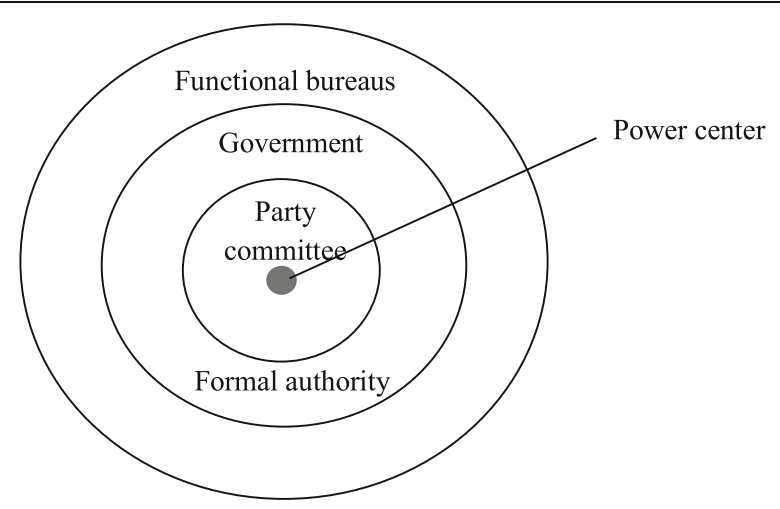

Fig. 2 Chinese Differentiated Authority

government administrative authority and then by functional bureaus professional authority. The above analysis can be summarized as:

Proposition 2.1 The Chinese government presents a ternary differentiated authority, and the authority statuses of the principals are completely different.

\section{Endogenous effects}

To some extent, the ternary differentiated authority generates endogenous interactive characteristic and behaviors among multiple principals.

The first is the one-way dependency of multiple principals. Traditional theory states that the multiple principal is a competitive relationship. However, the situation in China is different. The multiple principals of Chinese government create a relationship of one-way dependency, that is, the weak principal relies on the strong principal. This one-way dependency is divided into two categories. The first is successive dependency. Functional bureaus rely on the government, and the government relies on the party committee, thus forming a working model of government-led bureau coordination, or the party committee and government both take responsibility. The second category is leapfrog dependency (bypassing immediate authority). Functional bureaus bypass the immediate authority to compete for the party committee's attention, forming a working model that is party committee-led, and in which the government takes responsibility and functional bureaus coordinate.

Blau's analysis of US government agencies points out that authority dependence comes from normative internalization and psychological needs. Through formal or informal means, the bureaucratic system internalizes members' concept of hierarchical power and forms an inner psychological need. As a result, members would feel anxiety and frustration if the hierarchical power is destabilized and cannot be relied on (Blau 1955). This paper argues that in addition to normative internalization and psychological needs, the great difference of authority and resources is more important to the dependence relationship between a weak principal and a strong principal in the Chinese government. Strong principals control the important resources such as personnel matters, financial, and administrative and have a substantial power over other bureaus that will potentially cooperate with the weak principals. In other words, if one is not relying on strong principals and only on one's own strength, the work is often difficult to accomplish. 
The second characteristic is intra-group comparison. Traditional theory points out that multiple principals have the same status, form comparisons among the groups, and compete for the attention from agents through quantified reward and punishment. However, the multiple principals of the Chinese government do not form inter-group comparison but intra-group comparison, that is, the party committee, the government, and functional bureaus do not directly compare to each other but there is a relative comparison within functional bureaus. Reference groups and relative comparison theory provide the theoretical support for this phenomenon (Festinger 1954; Merton 1957; Weick 1979; Akerlof 1982). In a ternary differentiated authority, the authority statuses of principals are largely different, and principals are more likely to compare with principals who have similar functions and status. This view is supported by two cases from the Bureau of Justice in which the author participated in investigating. First, the Bureau of Justice does not compare its relative status in the provincial government to the Development and Reform Commission, Economic and Trade Commission, or other bureaus but compares to bureaus that have similar functions and status, such as public security, courts, or procuratorates. To some extent, the Bureau of Justice's sense of deprivation or satisfaction is affected by the relative improving or worsening status of public security, courts, and procuratorates in the provincial government. Second, when the Bureau of Justice visits the same bureau in other provinces, it has been welcomed. One of the reasons behind this is that the concerns of the Justice Bureau in other provinces are more likely to be the police, courts, and prosecutors in their own province.

Third, the affiliated incentive is stronger than quantified incentives. Traditional theory points out that the incentive intensity of multiple tasks depends on the quantification of reward and punishment, such as quantifying indicators for previously immeasurable tasks or rewarding and punishing some measurable indicators. The indicators of reward and punishment receive more attention from subordinates. However, this judgment is different from the behavior of the Chinese government. Some studies point out that the degree of quantified reward and punishment, such as the tasks of family planning and building a national sanitary city, is high (such as the "one-veto rule"), but that does not mean that these tasks will always be given priority by subordinates. Incentive effects were often better in those years when the party committee promoted this work, but when driven by secondary government leader, the incentive effects were less successful (Liu and Xiong 2015; Xu et al. 2015). These findings indicate that the effectiveness of the quantification of reward and punishment should be reconsidered; the leadership that drives tasks and the authority statuses of the affiliated principals should also be taken into account.

Based on this information, this paper proposes a new concept of affiliated incentive, that is, the authority status of the principal itself is an incentive. For example, the tasks assigned by higher-level party committee and the government still have a strong incentive even though the quantification of reward and punishment is low. Because the task of the party committee represents a political task, the choice to implement it or not reflects political loyalty. Therefore, the authority status of the principal is a powerful incentive signal. The incentive intensity of multi-tasks depends primarily on the authority status of the affiliated principal, followed by the degree of quantification of reward and punishment. If this analysis is reasonable, it can be inferred that there is an alternative relationship between the authority status of affiliated principal and the quantification of reward and punishment, that is, the higher the authority status of the principal, the 
lower the degree and the frequency of using quantified reward and punishment. This is because the incentive of authority status replaces the incentive of quantified reward and punishment to some extent. This phenomenon is confirmed by daily experience and observations. For example, since economic development is the key task of the party committee and government, its work rarely includes the "one-veto rule" and other terms of reward and punishment. In contrast, environmental management and other key tasks that are affiliated with functional bureaus more often include accountability, such as special rectification activities, key supervision, and the "one-veto rule."

The above discussion can be summarized as follows:

Proposition 2.2 The ternary differentiated authority results in one-way dependency between the multiple principals.

Proposition 2.3 The ternary differentiated authority results in intra-group comparison of the multiple principals.

Proposition 2.4 The incentive intensity of multiple tasks depends primarily on the authority status of affiliated principal, followed by the degree of quantification of reward and punishment.

\section{Organizational results}

To a certain extent, the above endogenous effects lead to the following organizational results. The first is the curvilinear competition for attention. In a ternary differentiated authority, the authority statuses of superior principals vary greatly. This means that it may be difficult for weak principals (functional bureaus) to effectively compete for the local government's attention if they rely solely on their own strength; they are therefore more likely to rely on the authority status of the strong principals (party committee) to pass the pressure downward so they can promote the policy implementation among local governments and bureaus. This process reflects the curvilinear competition for attention.

The second result is the coexistence of high-powered and low-powered incentives for the agent. Organizational economics theory suggests that multiple tasks tend to cause low-powered incentives (Wilson 1989; Dixit 1996; Dewatripont et al. 1999). In contrast, this paper argues that although local officials face multiple tasks, high-powered and low-powered incentives may still coexist. In the ternary differentiated authorities, the distribution of attention or the priorities of the work of local official is greatly affected by the authority status of superior, that is, the subordinate will pay more attention and resources to strong superior and less on weak superior, showing the coexistence of high-powered and low-powered incentives. Figure 3 depicts the multi-principal and multi-task structure of the Chinese government. The author forms the following propositions based on the above discussion:

Proposition 2.5 In a ternary differentiated authority, the principal circuitously competes for the agent's attention.

Proposition 2.6 In a ternary differentiated authority, there is a coexistence of high-powered incentive and low-powered incentive for the agent.

\section{Participant observation and multi-case analysis}

The construction of Chinese multi-principal and multi-task structure in this paper was based on the author's participant observation, comparison, analysis, and theorization of multiple cases. These cases are from the Bureau of Justice, the Bureau of Family 


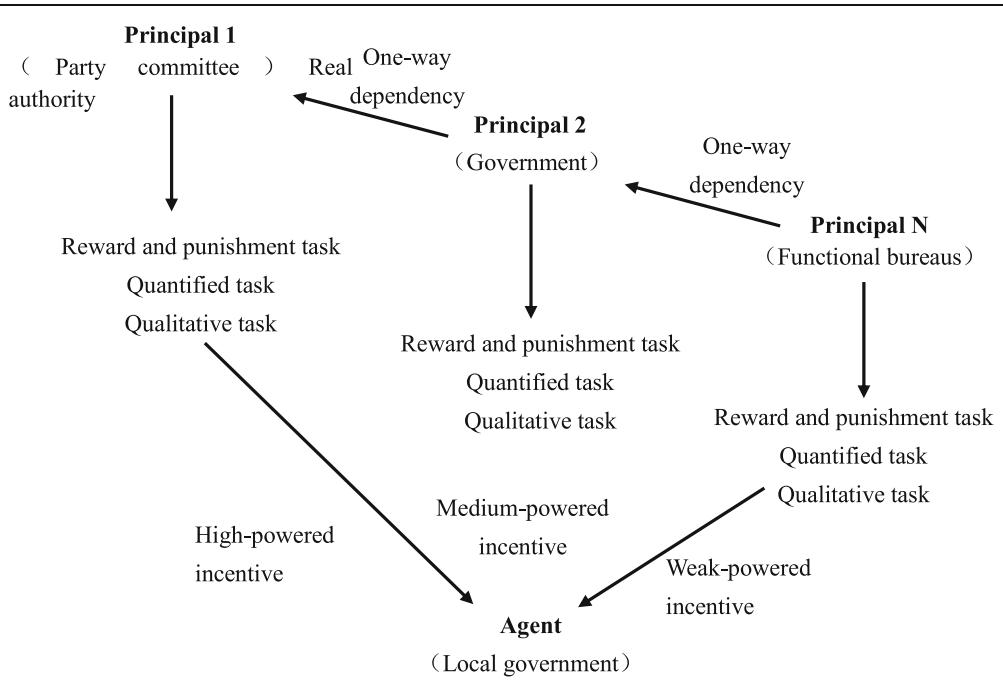

Organizational features:

(1) Multiple principals: One-way dependency; intra-group comparison

(2) Multiple tasks: Affiliated incentive > quantification of reward and punishment

(3) Agent: Coexistence of high-powered incentive with low-powered incentive

(4) Multiple principals compete for agent's attention: Curvilinear competitionSymbolic authority

Fig. 3 The Chinese multi-principal and multi-task structure

Planning, and the Bureau of City Management. The cases were obtained from two sources. The first was participant observation. The author closely observed the directors meeting, discussed documents from the justice office, and other processes of competing for the party committee and governmental attention. The second source was existing studies and secondhand data. The cases of Family Planning Commission and City Management Bureau were based on the existing research (Liu and Xiong 2015; Xu et al. 2015), and I also sorted out second-hand materials by using my own analytical framework. The above cases have at least two characteristics in common: one is the similar nature of the organization since the three cases were all from bureaus with dual leadership, the other was dynamic change. For example, the results of competing for the attention of the two institutional innovations of the provincial Justice Bureau are obviously different. One earned the attention of the provincial party committee and government, while the other only received the attention of the provincial government. Family Planning Bureau showed that policy enforcement was very strict in some years but relatively loose in other years. Additionally, before 2006, the cases of city management had been unsuccessful for more than a decade but finally succeeded in 2007 and 2008. These dynamic changes provide an opportunity for comparison and analysis that is similar to a natural experiment.

\section{The Bureau of Justice}

In order to promote institutional innovation, the provincial Bureau of Justice held several division chief meetings. Through these meetings, we can closely observe why and how a functional bureau promotes institutional innovation, what difficulties they face, and how obstacles can be overcome. 
The first act that the Bureau of Justice did was verifying basic conditions. As the last step of policy implementation, the effectiveness of grassroots judicial bureaus largely determines the effectiveness of the judicial policy. Grassroots judicial bureaus bear nine functions of the administration of justice, but they have problems such as low pay, short manpower, high work pressure, high official turnover, and insufficient funding. The first issue is lower rank and treatment. In the bureaucratic hierarchy, all the police stations and courts in the province are at the section or division level, but only $17.15 \%$ of justice stations are at the vice-section level or above. The second issue is a shortage of justice officials. The average number of officials in each justice office at the township level is 2.59. At present, there are still 224 justice offices with one officer and 4 with no officer. In addition, after the township organizational reform, the number of grassroots justice officials in the rural area stagnated or even decreased. The third issue is a shortage of office financial funding. The justice offices at county level do not have enough funding. Only one third of all judicial offices' receive annual funding higher than 20,000 RMB. The Deputy Director of the Bureau of Justice, who previously managed grassroots affairs, is well aware that this dilemma will induce the deviant behavior of grassroots officials:

There are many kinds of assessment from superiors, but when reaching to the grassroots offices with so few people the assessment is totally impossible! They all ignore you, nothing can be implemented, and all data is made up! If you ask them how many mediation cases have been done this year, they just add 10 percent to the number from last year, or boldly add 30 percent. They cheat level by level up to the State Council. None of the data is accurate. I tell you, I was in charge of grassroots affairs for three years; didn't I know them? I speak plainly; it is just because there are no hands, no money. If these problems are not solved, in the future there will be no one to carry out even more-scientific or more-valuable tasks, no implementation, no one to work. ... Regarding the grassroots justice cadres, if you want to call him to carry out a legal service or consultation once or twice, he has no problem, he will go there and beat drums and gongs, but he will not go the third time. The fourth time? Of course, he will not go. If his work did not get attention from superiors, he will not go, or he will go one more time to beat drums and gongs when superiors are checking his work. This is like the relationship between cats and mice; what's the use of it? If it stays like this, it can't last long! (20130718)

How can the Bureau of Justice solve the above difficulties? One possible way is to promote work by using professional authority, that is, ask all levels of the Bureau of Justice to report difficulties to the local governments and seek support from governments and relevant bureaus, including requesting more budget and officers. However, according to his long experience in governance, the deputy director believes that these methods will not work:

Of the relevant functional bureaus, some may give money (such as the financial bureau), some may give hands (such as the personnel bureau), some may give materials, and some may support you with their influence. Some do not give you money but give policy support. However when the Justice Bureau sent official letters to request help from these bureaus, they always moved it around. One day they said that they needed to do 
investigation and research, another day that they needed to consult with their leaders; they play you endlessly. ... They always ask for more document support. If the Provincial Bureau of Justice and Bureau of Finance do not issue a document, then the subordinate bureaus have no basis to help. For example, the local Justice Bureau runs to communicate with the Finance Bureau, the Finance Bureau staff will ask whether the provincial Bureau of Justice and the provincial Bureau of Finance have issued a document. (20130718)

Clearly, the conventional mode based on professional authority has limited effect; all the justice bureaus have a common experience in this. The director of the Policy and Regulation Bureau sighed: "If the Justice Bureau promotes work by ourselves, the authority is not enough. The provincial government leaders say that justice affairs are important, but in reality when the leaders are busy, justice affairs become secondary. When we need to spend money, it will be abandoned" (20130106). The deputy director complained: "If the provincial Bureau of Justice promotes work alone here, it is just like closing the doors and singing a song alone, it's no use. ... Only relying on ourselves the work certainly can't be done. After a few rounds it may become even worse and fail, especially if our head director is promoted and a new substitute comes to carry out the work. Then it is even more likely to fail" (20130718). The Director of the Bureau of Justice admits: "In our system of Justice Bureau, if you really want to promote your work more strongly, without a certain platform, without a certain carrier, you cannot make it bigger or stronger" (20130106).

What does the term "carrier" refer to here? One of the carriers is the power of the provincial government. The Director of the Counsel Management Office said: "The judicial work must be listed in the major planning on economic development by the provincial government, because if you do not put it in, in the future where does your money come from? If you still can't be put into the major economic and social development planning of the provincial government, the finance bureau will certainly not increase its budget in you. Then this is just like you're talking to yourself; it doesn't make much sense" (20130106). The Director of the Legal Aid Office said: "Of our provincial government tax income, the legal profession contributes approximately 700 million, but the government gives us very low budget. If I want to have legal aid services and funding, it is necessary to ask for support from the provincial government and the provincial financial bureau. Otherwise, how would you do it? How much money a year do your Justice Bureau have? No matter how you cry, if there is a lack of money, you cannot solve this problem" (20130718). Obviously, all the bureaus want to gain the support from the provincial government. The documents of the provincial education bureau were supported and forwarded by the provincial government; the Bureau of Justice took it as a good example and tried very hard to get a support from the provincial government and have their documents forwarded by the general office of the provincial government.

However, the deputy director thought that the other carrier, namely the provincial party committee and the provincial government, plays a bigger role. "The documents of the provincial education bureau are issued by the general office of the provincial government. However, I consider that if the two general offices of the provincial party committee and the provincial government can issue a document on behalf of the justice 
bureau, the efforts may be more powerful. The party committee has the absolute leadership, and their serious attention may even be better. Because local governments sometimes put aside the orders from the provincial government" (20130806). The Director of the Legal Aid Office also stressed the importance of the provincial party committee at a meeting: "I think the organizational evaluation of the provincial party committee is very important. Why? Last year the Organization Bureau of the Provincial Party Committee took the legal aid service as an evaluation index of the Scientific Outlook on Development of local government development. It's just a simple assessment, but it attracted great concern from the local government. The local government requires local judicial and administrative bureaus to understand the situation clearly, and know how this assessment was actually taken by the superiors. The government was very nervous, so the legal services and legal consultation are included in the performance evaluation system of the provincial party committee, and the party committee uses this evaluation system to push all levels of government to focus on and promote this work" (20130106).

Finally, the deputy director explained how to compete for the provincial party committee's attention:

We need to write a report to the main leadership of the provincial party committee. The report should state the significance, necessity, and feasibility to the provincial leaders who will make a decision. Speaking plainly, we just want to reach the provincial party secretary or governor of the province to get their instructions and comments. Without instruction from the leadership of the provincial party committee and provincial government, it's hard to get official documents from the "two general offices" [referring to the general offices of the provincial party committee and the provincial government]. We strive for the approval of the provincial party secretary and governor; with this material in our hands, lobbying the two general offices will be much easier. After the approval, plus the early policy research and framing, and plus the comments from the two general offices, it will be relatively easy to carry out the tasks. ... What should we do after the document is issued by the two general offices? That could be the struggle between the Bureau of Justice and other relevant bureaus, such as finance, development and reform, and policy support. A lot of relevant bureaus may be involved in coordination problems. As long as there is the comment from the two general offices, things will be easy. Based on this document, we can sign more agreements with other relevant bureaus as supplementary policies to promote our work. (20130718)

The above examples illustrate the three interior working modes of the Chinese government: functional bureaus, the government, and the party committee. The policy effectiveness ranking for the three models is party committee $>$ government $>$ functional bureaus. This can be verified from the subsequent development of the above-mentioned case. In the following two institutional innovations, one received instructions several times from the main leadership of the principal party committee as well as the official document from the two general offices. The other was only included in the outline of the provincial government plan. Although the reason behind this difference is unknown, its subsequent development can be traced through secondary data sources. Table 1 compares the subsequent 
Table 1 Comparison of the effects of competition for attention

\begin{tabular}{|c|c|c|c|}
\hline & Year & Contents & Overall effects \\
\hline \multirow[t]{2}{*}{$\begin{array}{l}\text { Legal service } \\
\text { (provincial government) }\end{array}$} & 2014 & $\begin{array}{l}\text { 1. Provincial government work report } \\
\text { 2. Provincial government's plan outline } \\
\text { 3. Ministry of Justice issued guidance } \\
\text { 4. Investigation of Vice-Minister } \\
\text { of Justice }\end{array}$ & \multirow{2}{*}{$\begin{array}{l}\text { 1. Financial support from } \\
\text { provincial and other local } \\
\text { finance bureaus } \\
\text { 2. No cooperation } \\
\text { between bureaus } \\
\text { 3. No assessment and } \\
\text { accountability } \\
\text { mechanisms, only } \\
\text { standardized plan }\end{array}$} \\
\hline & 2015 & $\begin{array}{l}\text { Joint investigation and research by the } \\
\text { vice-governor, deputy secretary of the } \\
\text { political and legal committee, and } \\
\text { deputy director of the general office } \\
\text { of the provincial government }\end{array}$ & \\
\hline \multirow[t]{2}{*}{$\begin{array}{l}\text { Legal adviser } \\
\text { (party committee) }\end{array}$} & 2014 & $\begin{array}{l}\text { 1. Two written instructions by the } \\
\text { secretary from the provincial } \\
\text { party committee } \\
\text { 2. Listed as a key point of the } \\
\text { provincial party standing committee } \\
\text { 3. Two general offices issued documents } \\
\text { 4. Teleconference of provincial committee, } \\
\text { Provincial People's Congress, and the } \\
\text { Political and Legal Committee }\end{array}$ & \multirow{2}{*}{$\begin{array}{l}\text { 1. All levels of party } \\
\text { committees issued } \\
\text { concrete implementations } \\
\text { or proposed regulations } \\
\text { 2. Defined the tasks and } \\
\text { responsibilities of relevant } \\
\text { bureaus, assured sufficient } \\
\text { financial support, and } \\
\text { established joint } \\
\text { meeting system } \\
\text { 3. Provincial People's } \\
\text { Congress formulated the } \\
\text { assessment system, dual } \\
\text { evaluation method, } \\
\text { People's Congresses at al } \\
\text { level assessed the } \\
\text { law-based administration } \\
\text { of governments } \\
\text { 4. Eight leaders of provincial } \\
\text { justice bureau were } \\
\text { responsible to supervise } \\
\text { eight jurisdictions }\end{array}$} \\
\hline & 2015 & $\begin{array}{l}\text { 1. Listed as priority supervised by the } \\
\text { provincial party standing committee } \\
\text { 2. Provincial government work report } \\
\text { 3. Deputy Secretary of the provincial party } \\
\text { committee, governor, secretary of the } \\
\text { political and legal committee, } \\
\text { members of the provincial } \\
\text { party standing committee, } \\
\text { executive vice governor, vice governor } \\
\text { held the summary meeting } \\
\text { 4. Vice-governor and deputy secretary } \\
\text { of the political and legal committee } \\
\text { held an on-site meeting } \\
\text { 5. The provincial finance bureau issued documents } \\
\text { 6. Vice-governor and deputy secretary of the } \\
\text { political and legal committee held a working meeting } \\
\text { 7. Provincial party committee, secretary of the } \\
\text { political and legal committee, and vice-governor } \\
\text { held a lawyer conference }\end{array}$ & \\
\hline
\end{tabular}

development between the two institutional innovations. It can be seen that the effect of attention competition on the provincial party committee is much bigger than the effect of attention competition on the provincial government. This is embodied in the leadership level, leadership authority, endorsement frequency, bureau coordination, and evaluation intensity.

\section{The Bureau of Family Planning}

The family planning policy is handled by a functional bureau. In order to let family planning bureaus attach importance to this work, all levels, from the State Family Planning Commission to local Family Planning Commissions, developed a set of internal performance assessments and rating methods. In addition, the State Family Planning Commission also asked all levels of planning bureaus to send official documents to each local government and bureau requiring coordination of family planning work. However, the overall result was poor. Local governments, relevant bureaus, and local family planning commissions did not actively cooperate. The reasons were, first, the incentive for local governments was weak. Since the State Family Planning Commission is not the direct superior of the local government, it does not have the power to promote local government leaders or make financial arrangements. Second, the incentive for relevant bureaus was weak. Without the support from local governments, relevant functional bureaus may not 
cooperate. The family planning bureau does not have an administrative authority over other bureaus and thus cannot command other bureaus. Third, the enthusiasm of the Family Planning Commission is weak. This is because local governments appoint the leaders of family planning commissions rather than the higher Family Planning Commission.

Without the government's intervention, the Family Planning Commission can only let people voluntarily comply with family-planning policy by means of public education, or seeking the help of other bureaus through an informal relationship. (Liu and Xiong 2015, 97)

Since the Family Planning Commission is a functional bureau of the local government, the local government should assign a deputy head of the government to be in charge of family planning work. This deputy head should have at least some role in promoting family planning work. However, this is not the case:

The deputy head assigned by the party and government is just nominal and only plays a role in oversight. The actual work is still led by the family-planning bureau. (Liu and Xiong 2015, 98)

The assigned deputy head of the government thus has only a symbolic meaning, and the effectiveness is poor.

For example, in 1982 and 1984, the effect of the authority of family planning was poor because the deputy county mayors were in charge (Liu and Xiong, 2015). Under what conditions can the role of these assigned leaders changes from nominal to substantial? If the party committee leads the family planning work and shares the responsibility with local governments, then the work of family planning becomes a political task. At this point, the higher-level leaders of the party and government face strong political incentives and will pass down the work pressure through the party system. In the two family planning campaigns of 1983 and 1991, governments at all levels established family planning leadership group led by the party leadership. The result of the implementation of the ligation policy was better in 1983 because the leader of the county party committees led the campaign rather than the deputy county mayors who led in 1982 and 1984. In addition, the campaign produced a better result in 1991 because the central party committee and government jointly issued a document stressing the shared responsibility between party and government. Under this high pressure, the family planning work was effectively promoted.

In March 1991, the Politburo Standing Committee listened to the General Director of the State Family Planning Commission Peng Peiyun's report on the population situation and concluded that the implementation of family planning should be carried out without delay. On April 7, Jiang Zemin stated, "The population problem has become an urgent problem" in a symposium on family planning with the participation of the main leaders of all provincial party committees and governments. In May, the "Decision of the Central Committee of the Communist Party of China and the State Council on strengthening family planning and strictly 
controlling population growth" was issued, which tightened the population policy that had been gradually loosening since the late 1980s. The document issued by the "two general offices" of the central party and government imposed a "one-veto rule" on the main leaders, which would deprive the leaders of bonuses, wards, and promotion. In severe cases, the leaders could be removed from office. (Liu and Xiong 2015, 98)

As a result of this promotion from the central party committee, family planning policy became the central work of party committees and governments at all levels, and all levels of government and bureaus have been included in this special work. Figure 4 summarizes the operation modes of family planning and shows that there are different modes of family planning work promotion-special and routine-between the party committees and functional bureaus. These cases show that the special mode of "party lead, government supervise, and functional bureaus coordinate" was most effective, followed by "government lead and functional bureaus cooperate." The least effective was the mode of "bureaus cooperate based solely on issuing official documents."

\section{The Bureau of City Management}

$\mathrm{Xu}$ Yan et al. (2015) studied the process of A City built a national sanitary city by taking long-term participant observation. They found an interesting phenomenon that before 2006, the attempts to build a sanitary city were unsuccessful for 17 years but eventually succeeded in 2007 and 2008. In 1989, a State Council document required both national and provincial sanitary city offices to inspect and grade sanitary work in all the cities each year. In 1991, the Patriotic Sanitation Campaign Committee of City A formulated a "plan to build a national sanitary city," and sent it on to the municipal government for approval. In the next year, the plan was approved and officially issued by the municipal government. The campaign was officially launched. City A sets up a campaign office commanded by the director of the general office of A government, taking charge of organizing, coordination, directing, and supervision. The municipal government held a mobilization meeting every time when the national and provincial inspection was about to take place. In early 2004, the mayor was directly involved in building a sanitary city, but his overall effect was limited. This is clearly indicated by the following case.

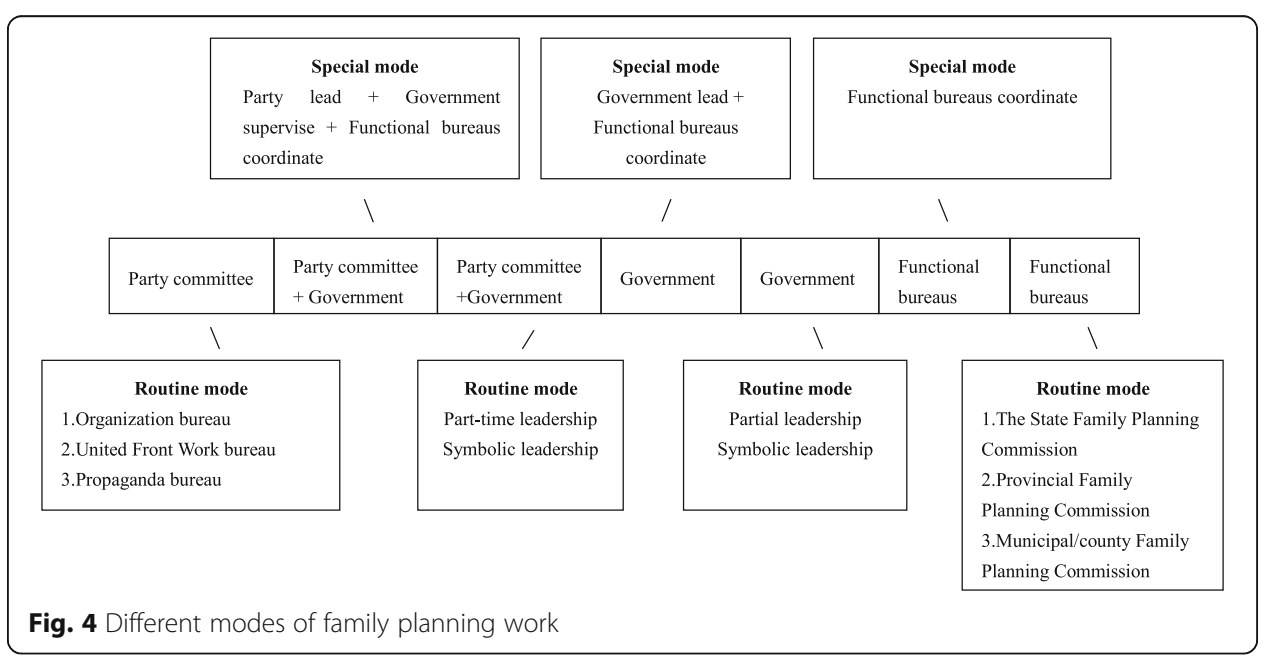


In 1993 the Environment Sanitation Bureau in City A planned to build a new landfill in Town J of County Z. Next year the landfill was included in the city's general development and the program was approved by the City Planning Commission. However, in August 1995 the Town J government submitted a report to the Environment Sanitation Bureau and the Project Construction Committee asking to cancel the landfill project because it would pollute J Town's environment and hurt economic development. After several unsuccessful negotiations with the Environment Sanitation Bureau, the municipal government office sent a letter to Z County Government in October 1996, asking for their support for the landfill project, but the request was not approved. City A government and County Z government negotiated on this issue for a long time, leading to the stalling of building the sanitary city [e.g., the landfill issue lasted for almost ten years]. Thus by 2006 the campaign failed even it was a government-led program. City A experienced its seventeenth defeat on this campaign, and was classified as a substandard sanitary city by the central government. (Xu et al. 2015, 38)

Beginning in 2007, the City A party committee and government led the campaign. Meanwhile, the goal of building a sanitary city was formally written into the city's Party Congress report. The party secretary and mayor endorsed it several times and mentioned the importance of building a sanitary city on different occasions. In addition, the municipal government and party committee broke the existing organizational boundaries and required the Urban Management Bureau, patriotic sanitation office, and three innovation offices to work on the campaign jointly. The city mayor replaced the director of the general office to command the campaign office. At a meeting, the mayor clarified the responsibility and accountability of the chief leaders in implementing the relevant policies and projects. In addition, the city party committee required the organization department, discipline commission, and personnel bureau to implement the relevant assessment and reward and punishment system. Through the "high order coordination" of the city party committee and government, the obstacles were broken through and the problems were solved. Thanks to the endorsement of party leaders, the effectiveness improved since 2007. Xu Yan and other scholars summarize this feature as "legitimacy loading," and believe that the higher the legitimacy loading, the more attention is obtained from the party committee and government, and the greater the possibility of mobilization of relevant resources ( $\mathrm{Xu}$ et al. 2015).

The ranks of endorsing leadership, the way they express their opinion, are important judgment standards for all functional bureaus. Before 2007 the deputy mayor or deputy secretary-general was responsible for the work. After 2007 the chief leaders of the city government provided endorsements, which significantly meant that the building sanitary city campaign changed from slogans to action. (Xu et al. 2015, 40)

Although the three cases were affiliated with different bureaus, they reflect the same operation logic of the government, that is, with the failure of the normal mode, they had to compete for the strong principal's attention and show a ternary differentiated authority in promoting the work: party committee $>$ government $>$ functional bureaus (see Table 2). 
Table 2 A multi-case study

\begin{tabular}{|c|c|c|c|}
\hline Organization & Party committees & Government & Functional bureaus \\
\hline $\begin{array}{l}\text { Working } \\
\text { mode }\end{array}$ & $\begin{array}{l}\text { Party leads }+ \text { government } \\
\text { supervise }+ \text { functional } \\
\text { bureaus coordinate }\end{array}$ & $\begin{array}{l}\text { Government supervise + functional } \\
\text { bureaus coordinate }\end{array}$ & $\begin{array}{l}\text { Functional bureaus } \\
\text { coordinate }\end{array}$ \\
\hline $\begin{array}{l}\text { Authority } \\
\text { type }\end{array}$ & $\begin{array}{l}\text { Leadership/political } \\
\text { authority = real authority }\end{array}$ & $\begin{array}{l}\text { Administrative authority = formal } \\
\text { authority }\end{array}$ & $\begin{array}{l}\text { Professional authority = } \\
\text { symbolic authority }\end{array}$ \\
\hline $\begin{array}{l}\text { Incentive } \\
\text { strategy }\end{array}$ & $\begin{array}{l}\text { High-powered affiliated incentive; } \\
\text { High-powered } \\
\text { incentives of quantified } \\
\text { reward and punishment } \\
\text { (party and government } \\
\text { accountability) }\end{array}$ & $\begin{array}{l}\text { Medium-powered } \\
\text { affiliated incentive; } \\
\text { Medium-powered incentives } \\
\text { of quantified reward } \\
\text { and punishment } \\
\text { (government accountability) }\end{array}$ & $\begin{array}{l}\text { Low-powered } \\
\text { affiliated incentive; } \\
\text { Low-powered incentives } \\
\text { of quantified reward } \\
\text { and punishment } \\
\text { (functional bureaus } \\
\text { accountability) }\end{array}$ \\
\hline $\begin{array}{l}\text { Incentive } \\
\text { intensity }\end{array}$ & High-powered incentives & Medium-powered incentives & Low-powered incentives \\
\hline $\begin{array}{l}\text { Governance } \\
\text { effect }\end{array}$ & Good & Unstable & Poor \\
\hline $\begin{array}{l}\text { Supporting } \\
\text { cases }\end{array}$ & $\begin{array}{l}\text { Judicial innovation } \\
\text { (legal adviser) } \\
\text { Family planning (1983/1991) } \\
\text { City management (2007-2008) } \\
\text { Reform of collective forest } \\
\text { rights (joint management of } \\
\text { five levels of party committees) } \\
\text { Environmental protection } \\
\text { (party and government } \\
\text { accountability in future) }\end{array}$ & $\begin{array}{l}\text { Judicial innovation (legal service) } \\
\text { Family planning (1982/1984) } \\
\text { City management (1989-2006) } \\
\text { Environmental protection } \\
\text { (government accountability) }\end{array}$ & $\begin{array}{l}\text { Judicial innovation } \\
\text { Family planning } \\
\text { City management } \\
\text { Reform of collective } \\
\text { forest rights } \\
\text { Environmental protection } \\
\text { (functional bureaus } \\
\text { accountability) }\end{array}$ \\
\hline
\end{tabular}

In fact, there are many similar cases. For example, the key to the successful reform of collective forest ownership was also due to the high-order coordination of five levels of party committees. When relying solely on functional bureaus, the effect is less significant.

When a functional bureau seeks the cooperation from other functional bureaus, because various functional bureaus have different power statuses within the government, some cooperating bureaus are more prominent or some bureaus are unwilling to cooperate due to relevant interests, then friction will occur. (He and Kong 2011, 76)

Another example is environmental protection. The former minister of Environmental Protection, Zhou Shengxian, believes that in the past, the chief leader of government was responsible for environmental protection, and the effect was limited. However, the pollution incident in the Inner Mongolia Tengger Desert was the starting point that in environmental protection, both the party committee and the government are held accountable.

\section{Extended discussion: the organization consequence of the multi-principal and multi-task structure}

The unique multi-principal and multi-task structure of the Chinese government have some positive influence that helps the party committee and government mobilize resources and coordinate state bureaucracies and functions. However, we believe that along with its inner logic, this differentiated authority also makes it possible to automatically and continuously derive some new problems that lead to negative functions. 
The first is the "Matthew effect" of authority status (one-way dependency mechanism). Because the weak principal unilaterally relies on the strong principal, this gradually increases authority status of the strong principal and weakens the authority status of the weak principal, forming the "Matthew effect" of authority status (Merton 1968).

In the actual operational process, it's easily decided to set up, upgrade, or expand an institution or even request additional financial support for the organization because of a speech or a meeting of the party leadership. (Zhao 2013)

In addition, because the functional bureaus lack real authority, they do not have enough dominance in the areas where the action is needed. Their professional authority is seriously constrained, and thus, they have to compete for the special mode of the party committee to promote their work. For example, among City A's various leadership groups established from 2002 to 2012, more and more groups were led by the party committee and government (Liu and Xie 2015). Zhao Shukai also points out, "What responsibilities and power belong to the party committee, and what belong to the functional bureaus should be institutionalized based on the rule of law, and should have clear organizational boundaries" (Zhao 2013). Obviously, China's process is contrary; the work could be promoted only when an administrative issue is turned into a political issue. In short, the one-way dependency mechanism leads to a growing difference between the party committee and functional bureaus. Meanwhile, the condition of constant solidifying, accumulation, and circulation formed a polarized "Matthew effect," and thus, the professional authority and autonomy of functional bureaus became more fragile (Dewatripont et al. 1999).

The second problem is the institutional innovation overflowing between functional bureaus (intra-group comparison mechanism). Under the influence of the differentiated authorities and intra-group comparison mechanism, in order to compete for the party and government's attention, the functional bureau may create one institutional innovation after another, thus forming institutional innovation overflowing. For example, the agriculture bureau wants to have some institutional innovation to demonstrate that China's agricultural foundation is weak and could endanger national food security so that the party committee will give more weight to agricultural work. The land bureau also appeals to the party committee by means of institutional innovations to stress that if the party committee does not pay attention to land affairs, it will be difficult for the local government and functional bureau to strictly adhere to the bottom line of arable land of 1.8 billion mu (about 300 million acres). In the early case study, the family planning bureau also sent a signal to the party committee that if population growth was not strictly controlled, it would lead to a baby boom, so family planning bureau must be focused on. The Ministry of Human Resources and Social Affairs calls on party committees and governments to attach importance to their work by describing the seriousness of the employment situation. The Women's Federation bureau holds a comparatively low position in the party committee, and in order to improve their organizational status, it used the institutional innovation of microcredit programs to attract the party committee's attention (Chen et al. 2013).

One consequence of this institutional innovation competition is the increased number of evaluations designed by the party committee and government. 
For example, in the 1980s, the strict evaluation was mainly used for family planning, financial revenue, and economic development. However, since the beginning of the 1990s, the previous evaluations remain in place while new evaluations continue to increase, such as the land usage, environment protection, petition and public security, and so forth (Zhao 2014).

The third problem is governance by rule of man rather than the rule of law (affiliated incentive mechanism). In a ternary differentiated authority, the affiliated incentive is a powerful signal for local governments and functional bureaus. Affiliated incentive refers to the incentive from the authority status of the principal with which tasks are affiliated. The authority status of affiliated principal is indicated by the political ranking of the leader. The party-affiliated incentive is higher than the government-affiliated incentive, and the government-affiliated incentive is higher than the functional bureauaffiliated incentive. One consequence of this situation is that it can lead to governance by the rule of man rather than the rule of law. Accordingly, people's dependency on political leaders is stronger than the trust in the political system. In recent years, with increasing instructions from the party leadership, local governments and functional bureaus fell into a strange cycle in which the work could be taken seriously only with instruction from the party committee leaders. For example, in 2013, the Development and Reform Commission of Shandong province received over 131 written instructions from the provincial party committee and government, including 21 from the provincial party secretary, 48 from the provincial governor, and 54 from the executive vice governor of the province. In 2014, the number skyrocketed to 600. The driving force of the skyrocketed number of written instructions is the affiliated incentive mechanism. In this trend, the rank of leadership's attention may continue to increase. In the past, the written instructions of the secondary leadership of the party committee and government would promote the work; however, with the increasingly intensive competition for top leader's attention, the power of secondary leaders' instruction continues to decline, concentrating the power in the hand of the top leader. As a result, today, only instructions from the top level of leadership are effective.

In short, the unique multi-principal and multi-task structure of the Chinese government may result in the above-mentioned negative effects. The driving force consists of the three mechanisms of one-way dependency, intra-group comparison, and affiliated incentives.

\section{Summary: the politics of attention}

An interesting research topic in economics is the "economy of attention," which emphasizes the importance of attention in the information-explosion era (Simon 1947; Goldhaber 1997). This paper argues that the attention competition within the Chinese government reflects the "politics of attention." This concept was proposed by Jones and Baumgartner (2005) and was used to analyze attention allocation in the agenda-setting process. The biggest difference between "politics of attention" and "economy of attention" is that the latter reflects a relation of supply and demand, while the former reflects a relationship of the distribution of authority, especially the competition deriving from the differentiated authority.

Compared to the previous study, the contributions of this paper can be broadly summarized as follows. First, it provides a new perspective on Chinese government 
behavior. Most existing studies analyze government behavior from a central-local perspective, looking at centralization and decentralization of state power, such as the analysis of the unification of the central government and the flexibility of the local government (Zhou 2011), administrative subcontract theory (Zhou 2014), and so on. This paper mainly studies government behavior from a horizontal perspective. In a dialog with traditional multi-principal and multi-task theory, the paper focuses on how the horizontally differentiated authority leads to attention competition and strategic behaviors between the multiple principals, with the coexistence of high-powered and low-powered incentives of local governments.

The second contribution is pointing out the multiple principals' heterogeneity and opening the "black box" of superiors. Zhou (2011) and Zhou (2014) consider central government and superior as a unity and do not distinguish its type, difference, or structure. In fact, principals are heterogeneous with different types of superiors, such as the party committee, government, and functional bureaus. This paper notes the heterogeneity of the multiple principals and points out that the heterogeneous multiple principles have differentiated authority.

The third contribution is recognizing the heterogeneity of the leaders of the principals. In recent years, researchers have analyzed the influence of leaders' attention on the agenda-setting process (Dutton 1997). These studies note the influence of leaders' attention on organizational decision-making, but researchers did not analyze the "leader" itself. This paper argues that leaders in various political positions have a different influence. On the one hand, the nature of the government organizations should be noted. Compared to the attention from functional bureau leaders, the attention from the party committee and the government have a greater influence on organizational decision-making. On the other hand, the ranking of leaders who are in government organization needs to be noted. Apparently, the top leaders are more likely to affect agenda-setting than the vice or deputy leaders. The chief leadership also has a greater influence on the organization than the leaders who have partial or part-time leadership. Therefore, different from the general research on agenda-setting, this paper points out the heterogeneity of leader.

The fourth contribution is advocating for a greater focus on the key variable of the party committee as a key research subject. In general, the studies on Chinese fragmented authoritarianism refer to party committee and government as "block"; the work of the party committee and the government is integrated. This conceptualization is suitable for the historical background of the integration of the party committee and the government. However, the party leading the government has become the norm in recent years; the party committees and the governments have different distributions of power, administration, and influence on subordinates. They should thus be treated differently, and attention needs to be paid to their heterogeneity. "Although the current studies on governance have many findings, there is a major flaw of a lack of "party" perspective. Whether in the actual reform process or academic research, they focus on government agencies themselves and somehow neglect the party organization" (Zhao 2014). From the analytical perspective of research method, on the one hand, party committees and governments need to be distinguished, and focus must be placed on differences in their heterogeneity and authority. On the other hand, a distinction must be made between the differences within the party committees. Local party committees 
often include a leadership system of "one party committee," "three party groups," and "a few Kouzi," The term "one party committee" refers to the local party committee members, with the Standing Committee presiding over the daily work. "Three party groups" refers to the three-party organizations affiliated with local people's congress, the people's government, and the people's political consultative conference. "A few Kouzi" refers to the several state functions of which the deputy party secretary or the Standing Committee are in charge, such as economic development, the relationship between the party and the masses, ideology, disciplinary inspection, politics and law, the united front, and so forth (Zhang 2015). Thus, there are significant differences inside the party committees. In the course of study, we should carefully analyze their different impacts on government operations.

There are still several important issues that need further study. The first is the internal process of acceptance or rejection by leaders. Limited by data, this paper only found the results of the competition for attention and could not capture the detailed decision-making process, which should be explored in future studies. The second issue is the competition for attention of vertically functional bureaus. The framework of this paper only applies to dual-leadership bureaus. In fact, vertically managed bureaus are also important in the Chinese government system, and many sectors and areas have adopted vertical management. Do vertically managed functional bureaus compete for the attention? What is the difference between the vertically managed functional bureau and the dual-leadership bureau? Future empirical research is still needed to verify, correct, and develop the analysis in this study.

Acknowledgements

Not applicable

Funding

This research was supported by a grant from the fundamental research funds for the central universities (No: 17wkzd25).

Availability of data and materials

Not applicable

\section{Authors' contributions}

Author analyzes how differentiated authority affects organizational interaction and triggers the correponding government behavior. The author read and approved the final manuscript.

Competing interests

The author declares that he/she has no competing interests.

Received: 26 December 2017 Accepted: 12 March 2018

Published online: 27 March 2018

References

Aghion, Philippe, and Jean Tirole. 1997. Formal and real authority in organizations. Journal of Political Economy 105: 1-29.

Akerlof, George A. 1982. Labor contracts as partial gift exchange. Quarterly Journal of Economics 97: 543-569.

Akerlof, George A. 1991. Procrastination and obedience. American Economic Review 81: 1-19.

Bernheim, D., and M. Whinston. 1986. Common agency. Econometrica 54: 923-942.

Blau, Peter M. 1955. The dynamics of bureaucracy: A study of interpersonal relations in two government agencies. Chicago, IL: University of Chicago Press.

CCCPC Party Literature Research Office. 1993. Selected works of Mao Zedong. Vol. 6. Beijing: People's Publishing House.

Chen, Jiajian, Huimin Bian, and Xiangshu Deng. 2013. Bureaucratic structure and policy implementation. Sociological Studies 6: 1-20.

Cohen, Michael D., James G. Marchand, and Johan P. Olsen. 1972. A garbage can model of organizational choice. Administrative Science Quarterly 17: 1-25.

Dewatripont, Mathias, lan Jewitt, and Jean Tirole. 1999. The economics of career concerns, part II: Application to missions and accountability of government agencies. Review of Economic Studies 66: 199-217.

Dixit, Avinash K. 1996. The making of economic policy: A transaction cost politics perspective. Cambridge: MIT Press. 
Dutton, J.E. 1997. Strategic agenda building in organizations. In Organizational decision making, ed. Shapira Zur, 81-107. Cambridge: Cambridge University Press.

Festinger, Leon. 1954. A theory of social comparison processes. Human Relations VII 7: 117-140.

Gibbons, Robert. 1992. A primer in game theory. Harvester: Wheatsheaf.

Goldhaber, Michael H. 1997. The attention economy and the net. First Monday 2: 23-26.

He, Donghang, and Fanbin Kong. 2011. Chinese experience in the implementation of public policy. Social Sciences in China 5: 61-79.

Holmstrom, Bengtand, and Paul Milgrom. 1991. Multitask principal-agent analyses: Incentive contracts, asset ownership, and job design. Journal of Law, Economics and Organization 7: 24-52.

Jones, Bryan D., and Frank R. Baumgartner. 2005. The politics of attention: How government prioritizes problems. Chicago, IL: University of Chicago Press.

Lian, Hong. 2015. The multiple perspectives and interdisciplinary study of attention allocation. Sociological Studies 4: 215-241.

Lian, Hong. 2016. Sociological analysis of weak ranking incentive - the case of environmental protection. Social Sciences in China 1: 82-99.

Liu, Ji, and Cai Xiong. 2015. Explaining China's policy deformation: Tiao/Kuai authority relations under campaign-style governance. Journal of Public Administration 6: 88-112.

Liu, Junqiang, and Yanhui Xie. 2015. Unconventional tasks, officials' attention and the governance mechanism of China's local coordination group-a study of province a (2002 - 2012). CASS Journal of Political Science 4: 84-97.

Merton, Robert K. 1940. Bureaucratic structure and personality. Social Forces 18 (4): 560-568.

Merton, Robert K. 1957. Social theory and social structure. New York: Free Press.

Merton, Robert K. 1968. The Matthew effect in science. Science 159 (3810): 56-63.

Meyer, John W., and Brian Rowan. 1977. Institutionalized organizations: Formal structure as myth and ceremony. American Journal of Sociology 83 (2): 340-363.

Michels, Robert. 1968. Political party. New York: Free Press.

Rubinstein, Ariel. 1982. Perfect equilibrium in a bargaining model. Econometrica 50: 97-109.

Simon, Herbert A. 1947. Administrative behavior. New York: The Free Press.

Tirole, Jean. 1994. The internal organization of government. Oxford Economic Papers 46 (1): 1-29.

Weber, Max. 1946. In Max Weber: Essays in Sociology, trans, ed. H.H. Gerthand and C.W. Mills. New York: Oxford University Press.

Weick, Karl. 1979. The social psychology of organizing. New York: McGraw Hill.

Wilson, James Q. 1989. Bureaucracy: What government agencies do, and why they do it. New York: Basic Books.

Xiaotong, Fei. 1998. Rural China fertility system. Beijing: Peking University Press.

$\mathrm{Xu}$, Yan, Nana Fan, and Nabo Chen. 2015. Legitimacy loading: A new explanation for the political campaign in China-18 years of 'building a National Sanitary City' in a Chinese city. Journal of Public Administration 2: 22-46.

Yu, Lihong, and Xizhan Guan. 2005. A survey on multi-principal incentive theory and its applications. Industrial Economics Research 3: 54-63.

Zhang, Jingen. 2015. Local government management. Beijing: Peking University Press.

Zhao, Shukai. 2013. Crisis in and reform of governance by county and township governments-structural adjustment in distribution of management power and interaction mode. People's Tribune Frontiers 11: 14-30.

Zhao, Shukai. 2014. Primary level government: Institutional conflicts and crisis governance. People's Tribune 5: 46-51.

Zhou, Li an. 2007. Governing China's local officials: An analysis of promotion tournament model. Economic Research Journal 7: 36-50.

Zhou, Li an. 2014. Administrative subcontract. Chinese Journal of Sociology 6: 1-38.

Zhou, Xueguang. 2011. The authority system and effective governance: The institutional logic of state governance in contemporary China. Open Times 10: 67-85.

Zhou, Xueguang, and Hong Lian. 2011. An analysis model of negotiation between the upper and lower level government-a case study of the environmental protection bureau. Social Sciences in China 5: 80-96.

\section{Submit your manuscript to a SpringerOpen ${ }^{\circ}$ journal and benefit from:}

- Convenient online submission

- Rigorous peer review

- Open access: articles freely available online

- High visibility within the field

- Retaining the copyright to your article

Submit your next manuscript at $\boldsymbol{s p r i n g e r o p e n . c o m ~}$ 